\title{
GTF3C4 wt Allele
}

National Cancer Institute

\section{Source}

National Cancer Institute. GTF3C4 wt Allele. NCI Thesaurus. Code C52631.

Human GT F3C4 wild-type allele is located in the vicinity of 9q34.13 and is approximately $25 \mathrm{~kb}$ in length. This allele, which encodes general transcription factor $3 \mathrm{C}$ polypeptide 4 protein, plays a role in the mediation of RNA polymerase III function. 